Research Article

\title{
Clinical study of hydatid disease
}

\author{
Amit N. Pothare, Amol V. Deshpande, Vipul V. Nandu*
}

Department of Surgery, Shri V.N. Govt. medical college, Yavatmal, Maharashtra, India

Received: 31 May 2016

Accepted: 02 July 2016

*Correspondence:

Dr. Vipul V. Nandu,

E-mail: dr.vipulnandu@gmail.com

Copyright: (C) the author(s), publisher and licensee Medip Academy. This is an open-access article distributed under the terms of the Creative Commons Attribution Non-Commercial License, which permits unrestricted non-commercial use, distribution, and reproduction in any medium, provided the original work is properly cited.

\section{ABSTRACT}

Background: Hydatid cyst is zoonosis caused due to Echinococcus species Echinococcus granulosus. In developing countries like India, Iran, China and Mediterranean countries it is still remains a major problem. It can involve any organ and can mimic almost any pathological condition. Complication associated rather than disease itself, are difficult to treat. Aims was to study about; (1) The major organs involved by hydatid disease. (2) The best treatment modality depending upon the site, size and organ involving the cyst. (3) The preoperative and postoperative complications of hydatid disease.

Methods: Prospective clinical study was conducted on 58 patients. All patients diagnosed as hydatid disease mainly by ultrasound or CT scan and then treated either operatively or non-operatively were included in this study. The choice of surgical procedure was guided by site, size, organ involving the cyst and associated complications. The patients were followed up for a period of 6 months.

Results: The highest incidence was found in 3rd decade $(27.59 \%)$. It is more common in females $(70.69 \%)$. Liver is most common organ involved $(86.2 \%)$. Ultrasonography was the imaging modality of choice for diagnosis. Partial cystectomy with omentoplasty with external drainage was most commonly performed surgery after through irrigation with scolicidal solution. Presence of cystobiliary communications was most common intra-operative complication (22\%). The mean duration of stay after surgery was about 9.34 days.

Conclusions: Hydatid disease is still a major problem in rural agricultural population. Surgery is most widely acclaimed procedure for treatment of hydatid.

Keywords: Hydatid disease, Echinococcus granulosus

\section{INTRODUCTION}

Hydatid cyst is zoonosis caused due to Echinococcus species - Cestode parasite commonly known as small tape worms of carnivorous animals. There are predominantly two species affecting the human population; Echinococcus granulosus and Echinococcus multilocularis. It was first described by Hippocrates as "Liver full of water". ${ }^{\text {"With }}$ evolving science, advanced diagnostic and treatment facilities and above all better living conditions in developed countries, the disease now being limited only to agriculture and ranch work associated people of Australia, Latin America, Eastern Europe and New Zeland. ${ }^{2}$
But in developing countries like India, Iran, China and Mediterranean countries it is still remains a major problem. In India the most affected areas are Central India, Andhra Pradesh and Tamil Nadu. ${ }^{3}$ It can involve any organ and can mimic almost any pathological condition. Complication associated rather than disease itself, are difficult to treat. ${ }^{2}$

Although hydatid cysts can be treated by various modalities, like surgery, chemotherapy, and or percutaneous aspiration, but surgery by far remains the gold standard for treatment among day by day evolving new procedures. It is the only treatment which is applicable over the entire spectrum of disease. 


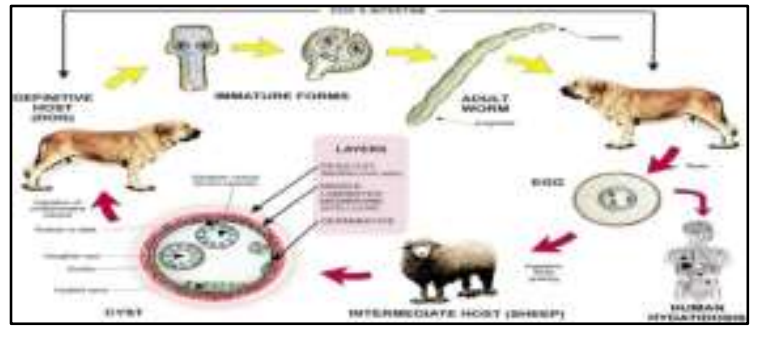

Figure 1: Life cycle of echinococcus granulosus.

\section{METHODS}

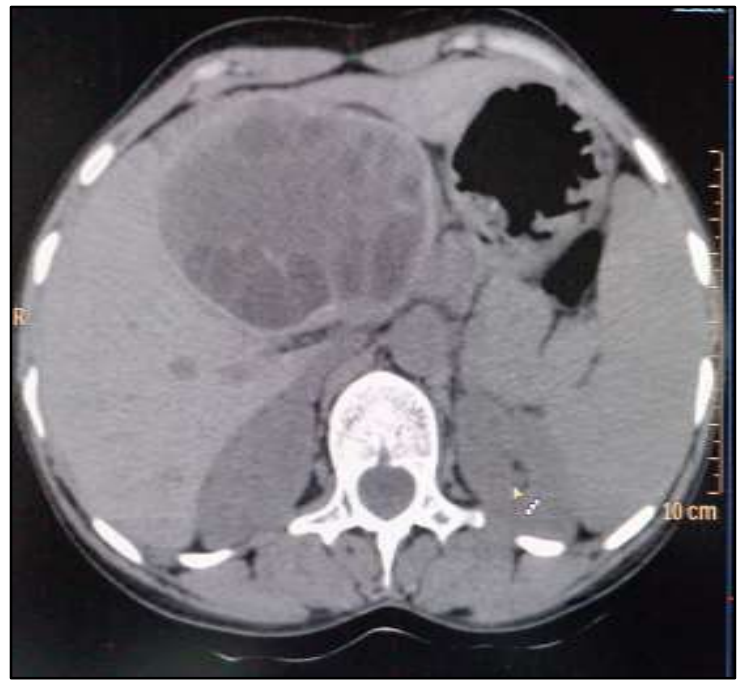

Figure 2: CT Abdomen showing (i) hydatid cyst of liver with multiple daughter cysts.

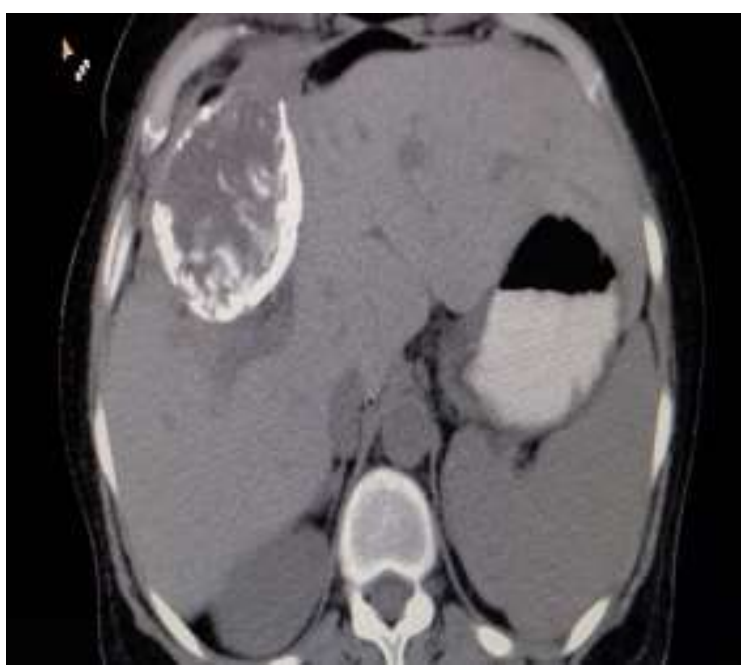

Figure 2: CT abdomen showing (ii) calcified hydatid cyst of liver.

Prospective clinical study conducted from July 2011-December 2013. All patients diagnosed as hydatid disease mainly by ultrasound or CT scan and then treated either operatively or nonoperatively in our institute. All the diagnosed cases were subjected to detailed history and physical examination with all the base line investigations. Ultrasound remains the main diagnostic modality and CT done only for those cases which are difficult to assess on USG.

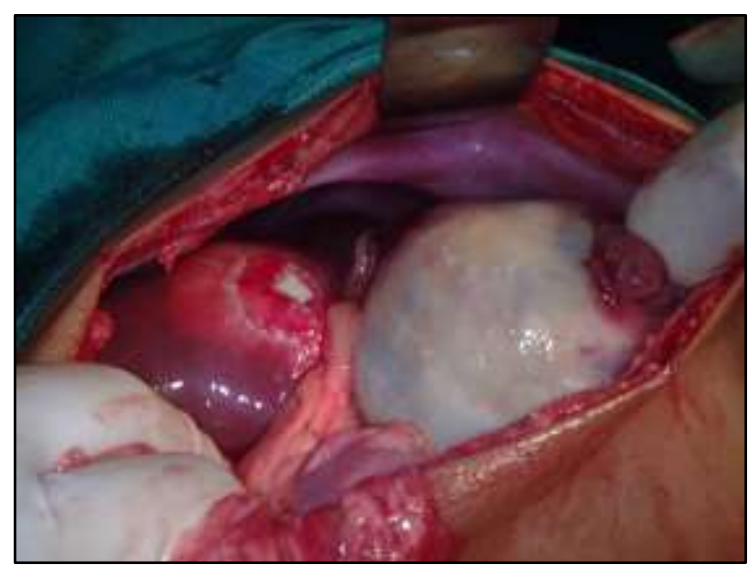

Figure 3: Intra-op photo showing bilateral liver hydatid cyst.

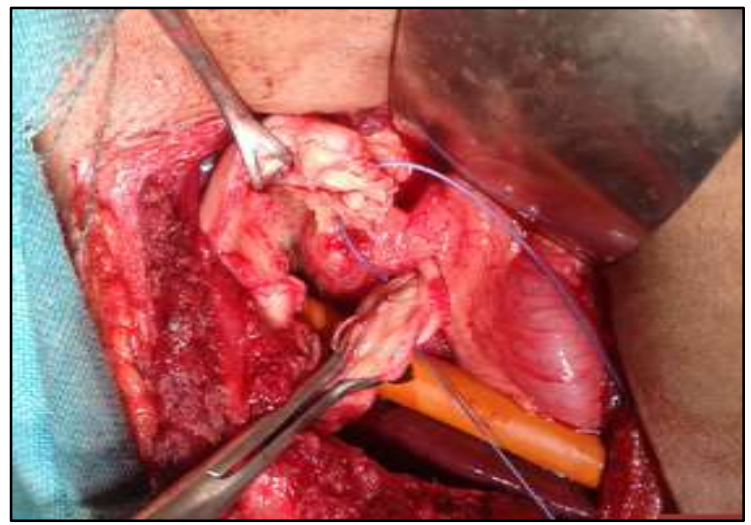

Figure 4: Partial cystectomy with omentoplasty.

Patients were operated after a preoperative Albendazole therapy for 28 days in dose of $10 \mathrm{mg} / \mathrm{kg}$ and postoperatively all patients were put on Albendazole three course of 28 weeks each with 1 week gap in between. The choice of surgical procedure was guided by site, size, organ involving the cyst and associated complications.

The patients who are unfit for any surgical procedure are started on Albendazole therapy for 6 months, 28 days cycle with 1 week gap in between, in dose of $10 \mathrm{mg} / \mathrm{kg}$. The patients were followed up for a period of 6 months. Two times a month for three months, and then monthly. In follow up period, patients were subjected to history, USG and routine investigations. 


\section{RESULTS}

Table 1: Organ involvement in hydatid disease.

\begin{tabular}{|lll|l|}
\hline $\begin{array}{l}\text { Organ } \\
\text { involved }\end{array}$ & $\begin{array}{l}\text { Present } \\
\text { study }\end{array}$ & $\begin{array}{l}\text { Hakan et } \\
\mathbf{a l}^{4}(\mathbf{2 0 0 1}) \\
\mathbf{4 4 6} \\
\text { patients }\end{array}$ & $\begin{array}{l}\text { Polat et al }^{5} \\
(2003) \\
368 \text { patients }\end{array}$ \\
\hline Liver & $86.20 \%$ & $82.7 \%$ & $74.8 \%$ \\
\hline Lung & $10.35 \%$ & $20.8 \%$ & $24.1 \%$ \\
\hline Spleen & $6.9 \%$ & $4.27 \%$ & $0.8 \%$ \\
\hline $\begin{array}{l}\text { Omentum } \\
\text { and } \\
\text { Peritoneum }\end{array}$ & $8.6 \%$ & $1.12 \%$ & $3.8 \%$ \\
\hline Kidney & $1.72 \%$ & $1.12 \%$ & $3.8 \%$ \\
\hline Muscle & $1.72 \%$ & $1.12 \%$ & $0.8 \%$ \\
\hline Bone & $0 \%$ & $0.8 \%$ & $0.8 \%$ \\
\hline Brain & $0 \%$ & $1.12 \%$ & $3.8 \%$ \\
\hline Others & $0 \%$ & $1-2 \%$ & $1-2 \%$ \\
\hline
\end{tabular}

Table 2: Single or multiple organ involvement.

\begin{tabular}{|llll|}
\hline Cysts & $\begin{array}{l}\text { Magistrelli et } \\
\mathbf{a l}^{6}(\%)\end{array}$ & $\begin{array}{l}\text { Akther et } \\
\mathbf{a l}^{7}(\%)\end{array}$ & $\begin{array}{l}\text { Present } \\
\text { study }\end{array}$ \\
\hline Single & $87.40 \%$ & $90.59 \%$ & $94 \%$ \\
\hline Multiple & $12.60 \%$ & $9.40 \%$ & $6 \%$ \\
\hline
\end{tabular}

Table 3: Lobe involvement.

\begin{tabular}{|c|c|c|c|}
\hline $\begin{array}{l}\text { Lobe } \\
\text { involved }\end{array}$ & $\begin{array}{l}\text { Kalinova } \\
\text { et } \mathbf{a l}^{8}\end{array}$ & $\begin{array}{l}\text { Akther } \\
\text { et } \mathbf{a l}^{7}\end{array}$ & Present Study \\
\hline Right & $77.95 \%$ & $62.5 \%$ & $72 \%$ \\
\hline Left & $15.75 \%$ & $26.13 \%$ & $24 \%$ \\
\hline Both & $6.30 \%$ & $11.36 \%$ & $4 \%$ \\
\hline
\end{tabular}

Table 4: Size of liver cyst.

\begin{tabular}{|c|c|c|c|}
\hline $\begin{array}{l}\text { Size of } \\
\text { cyst }\end{array}$ & $\begin{array}{l}\text { Kalinova } \\
\text { et } \mathbf{a l}^{8}\end{array}$ & $\begin{array}{l}\text { Chowbey PK } \\
\text { et } \mathrm{al}^{9}\end{array}$ & $\begin{array}{l}\text { Present } \\
\text { Study }\end{array}$ \\
\hline $\begin{array}{l}\text { Mean } \\
\text { size }\end{array}$ & $9.1 \mathrm{~cm}$ & $9.2 \mathrm{~cm}$ & $9.4 \mathrm{~cm}$ \\
\hline
\end{tabular}

Table 5: Chief complaints/clinical presentation.

\begin{tabular}{|llll|}
\hline Complaints & Percentage & $\begin{array}{l}\text { LAnger } \\
\text { et al }\end{array}$ & $\begin{array}{l}\text { Akther } \\
\text { et al }^{7}\end{array}$ \\
\hline $\begin{array}{l}\text { Pain in } \\
\text { abdomen }\end{array}$ & $84 \%$ & $87 \%$ & $89.47 \%$ \\
\hline $\begin{array}{l}\text { Lump in } \\
\text { abdomen }\end{array}$ & $50 \%$ & $59 \%$ & $85.26 \%$ \\
\hline Jaundice & $18 \%$ & $21 \%$ & $6.31 \%$ \\
\hline Fever & $20 \%$ & $23 \%$ & $26.31 \%$ \\
\hline Asymptomatic & $0 \%$ & $13 \%$ & \\
\hline
\end{tabular}

Table 6: Investigation for abdominal hydatid.

\begin{tabular}{|llll|}
\hline $\begin{array}{l}\text { Modality of } \\
\text { diagnosis }\end{array}$ & $\begin{array}{l}\text { Sensitivity } \\
\text { in present } \\
\text { study }\end{array}$ & $\begin{array}{l}\text { Pedrosa } \\
\text { et al }^{11} \\
\text { Sensitivity } \\
\%\end{array}$ & $\begin{array}{l}\text { Kalinova } \\
\text { et al }^{\mathbf{8}} \\
\text { Sensitivity } \\
\%\end{array}$ \\
\hline Ultrasonography & $92.72 \%$ & $98 \%$ & $90 \%$ \\
\hline $\begin{array}{l}\text { Computed } \\
\text { tomography }\end{array}$ & $100 \%$ & $99-100 \%$ & $98 \%$ \\
\hline
\end{tabular}

Table 7: Investigation for thoracic hydatid.

\begin{tabular}{|lll|}
\hline $\begin{array}{l}\text { Modality of } \\
\text { diagnosis }\end{array}$ & $\begin{array}{l}\text { Sensitivity } \\
\text { in present } \\
\text { study }\end{array}$ & Sharifi Mood et al \\
\hline X Ray & $66.67 \%$ & $69 \%$ \\
\hline Ultrasonography & $100 \%$ & \\
\hline CT scan & $100 \%$ & $92 \%$ \\
\hline
\end{tabular}

Table 8: Operative modality for Hydatid cyst.

\begin{tabular}{|llll|}
\hline $\begin{array}{l}\text { Operative } \\
\text { procedure }\end{array}$ & $\begin{array}{l}\text { Present } \\
\text { study }\end{array}$ & $\begin{array}{l}\text { Tariq E. } \\
\text { Al- } \\
\text { aubaidi }\end{array}$ & $\begin{array}{l}\text { Sarmast et } \\
\mathbf{a l}^{14}\end{array}$ \\
\hline $\begin{array}{l}\text { Partial } \\
\text { cystectomy } \\
\text { with } \\
\text { omentoplasty }\end{array}$ & $11.12 \%$ & $46.67 \%$ & $73 \%$ \\
\hline $\begin{array}{l}\text { Partial } \\
\text { cystectomy } \\
\text { with external } \\
\text { drainage }\end{array}$ & $16.67 \%$ & $47.92 \%$ & $89 \%$ \\
\hline $\begin{array}{l}\text { Partial } \\
\text { cystectomy } \\
\text { with } \\
\text { omentoplasty } \\
\text { and external } \\
\text { drainage }\end{array}$ & $53.84 \%$ & $25 \%$ & - \\
\hline $\begin{array}{l}\text { Partial } \\
\text { cystectomy } \\
\text { with evacuation } \\
\text { and closure }\end{array}$ & - & & \\
\hline $\begin{array}{l}\text { Segmental } \\
\text { resection }\end{array}$ & - & $40 \%$ & $41 \%$ \\
\hline $\begin{array}{l}\text { Total } \\
\text { pericystectomy }\end{array}$ & - & - & - \\
\hline
\end{tabular}

Table 9: Comparison with radical surgeries.

\begin{tabular}{|llll|}
\hline $\begin{array}{l}\text { Compared } \\
\text { to radical } \\
\text { procedures }\end{array}$ & $\begin{array}{l}\text { Schmidt- } \\
\text { Mattiesen } \\
\text { A et al }\end{array}$ & $\begin{array}{l}\text { Alfieri S et } \\
\text { al }^{\mathbf{1 6}}\end{array}$ & $\begin{array}{l}\text { Present } \\
\text { study }\end{array}$ \\
\hline $\begin{array}{l}\text { Complication } \\
\text { rate }\end{array}$ & $38.5 \%$ & $19 \%$ & $34 \%$ \\
\hline Mortality & $2.27 \%$ & $1.12 \%$ & $0 \%$ \\
\hline Recurrence & $0 \%$ & $1.12 \%$ & $6 \%$ \\
\hline
\end{tabular}


Table 10: Intraoperative complications.

\begin{tabular}{|c|c|c|c|}
\hline Complications & $\begin{array}{l}\text { Langer } \\
\text { et } \mathbf{a l}^{10} \\
\mathbf{3 5} \\
\text { patients }\end{array}$ & $\begin{array}{l}\text { Silva et } \\
\text { al }^{17} \\
30 \\
\text { patients }\end{array}$ & $\begin{array}{l}\text { Present } \\
\text { study }\end{array}$ \\
\hline $\begin{array}{l}\text { Presence of } \\
\text { cystobiliary } \\
\text { communications }\end{array}$ & $31.42 \%$ & $50 \%$ & $22 \%$ \\
\hline $\begin{array}{l}\text { Injury to hollow } \\
\text { viscera }\end{array}$ & $0 \%$ & $0 \%$ & $0 \%$ \\
\hline $\begin{array}{l}\text { Contamination of } \\
\text { abdominal cavity } \\
\text { with scolices }\end{array}$ & $5.71 \%$ & $6.67 \%$ & $16 \%$ \\
\hline Anaphylaxis & $0 \%$ & $0 \%$ & $2 \%$ \\
\hline $\begin{array}{l}\text { Injury to biliary } \\
\text { tree }\end{array}$ & $0 \%$ & $0 \%$ & $0 \%$ \\
\hline Haemorrhage & $0 \%$ & $0 \%$ & $0 \%$ \\
\hline
\end{tabular}

Table 11: Postoperative complications.

\begin{tabular}{|c|c|c|c|}
\hline $\begin{array}{l}\text { Post- } \\
\text { operative } \\
\text { complication }\end{array}$ & $\begin{array}{l}\text { Langer } \\
\text { et }^{10}{ }^{10} \\
35 \\
\text { patients }\end{array}$ & $\begin{array}{l}\text { Silva et } \\
\text { al }^{17} \\
30 \\
\text { patients }\end{array}$ & $\begin{array}{l}\text { Present } \\
\text { study } \\
50 \text { patients }\end{array}$ \\
\hline Bile leak & $33.34 \%$ & $25 \%$ & $20 \%$ \\
\hline Biliary fistula & $0 \%$ & $0 \%$ & $0 \%$ \\
\hline $\begin{array}{l}\text { Sub-phrenic } \\
\text { abscess }\end{array}$ & $3.34 \%$ & $0 \%$ & $0 \%$ \\
\hline Liver abscess & $16.66 \%$ & $0 \%$ & $0 \%$ \\
\hline $\begin{array}{l}\text { Respiratory } \\
\text { complications }\end{array}$ & - & $10 \%$ & $14 \%$ \\
\hline $\begin{array}{l}\text { Wound } \\
\text { complications }\end{array}$ & $16.64 \%$ & $4 \%$ & $22 \%$ \\
\hline
\end{tabular}

Table 12: Delayed complications.

\begin{tabular}{|llll|}
\hline $\begin{array}{l}\text { Delayed } \\
\text { complications }\end{array}$ & $\begin{array}{l}\text { Present } \\
\text { study }\end{array}$ & $\begin{array}{c}\text { Langer } \\
\text { et al }^{10} \\
35 \\
\text { patients }\end{array}$ & $\begin{array}{c}\text { Silva et al } \\
30 \text { patients }^{17}\end{array}$ \\
\hline Recurrence & $6 \%$ & $8.57 \%$ & $6.67 \%$ \\
\hline $\begin{array}{l}\text { Incisional } \\
\text { hernia }\end{array}$ & $4 \%$ & - & - \\
\hline
\end{tabular}

Table 13: Duration of hospital stay.

\begin{tabular}{|lll|}
\hline Duration of stay & $\begin{array}{l}\text { No. of } \\
\text { patients }\end{array}$ & Percentage \\
\hline $\begin{array}{l}\text { Less than or equals } \\
\text { to 7 days }\end{array}$ & 30 & $51.72 \%$ \\
\hline 8-14 days & 23 & $39.65 \%$ \\
\hline More than 14 days & 5 & $8.63 \%$ \\
\hline
\end{tabular}

\section{DISCUSSION}

Hydatid surgeries constitute $2.08 \%$ of total major surgeries. Total patients included in study were 58 .
The highest incidence was found in $3^{\text {rd }}$ decade $(27.59 \%)$ followed by $5^{\text {th }}$ decade $(24.12 \%)$. The disease was found to be, more common in females as compared to males $(70.69 \%$ in females and $29.31 \%$ in males). Hydatid disease is more commonly seen in agriculture related population, but females affected more, belongs to nonagriculture related population. Hydatid disease is more commonly associated with agriculture related cattle in the area, mainly cows, goats, and buffalos as compared to dogs.

Liver is most common organ involved in hydatid disease $(86.2 \%)$, followed by lung (10.35\%) followed by Spleen (6.9\%). Kidney, muscle, omentum and peritoneum are rarely involved. These findings are compatible to all the previous studies like Hakan et al. ${ }^{4}$

Single organ involvement was more common $(84.49 \%)$ than multiple organ involvement (15.51\%). These findings are similar to those of previous studies, Akther et al7; and Magistrelli et al. ${ }^{6}$

In hydatid disease of liver, most common lobe involved is right lobe (72\%) followed by left lobe $(24 \%)$. Both lobes are involved in $4 \%$ of patients. These findings were comparable with previous studies of Akther et al; and Kalinova et al. ${ }^{7,8}$

The more common involvement of right lobe in liver hydatid could be explained on the basis of:

- Portal vein divided into two halves, and the major portion supplies the right lobe of liver.

- The bulk of right lobe is large as compared to left.

Single liver cyst was present in $94 \%$ percent of patients, while in $6 \%$ of patients multiple cysts were present. The mean size was calculated by taking the mean of maximum diameter of each cyst. The mean size was $9.4 \mathrm{~cm}$. So the mean size was comparable with Kalinova et al and Chowbey et al. ${ }^{8,9}$

The main presenting symptom of liver hydatid, was dull aching abdominal pain in epigastrium and right hypochondrium (84\%) followed by abdominal lump in about $50 \%$. These results are nearly similar to those in previous studies of Langer et al; Akther et al. ${ }^{7,10}$

For abdominal hydatid, ultrasound is initial diagnostic modality of choice with sensitivity to accurately diagnose the disease about $92.72 \%$ and CT scan is done only for those cases, in which ultrasound fails due to patient related difficulties (for example obesity, excessive intestinal gas, 
abdominal wall deformities, previous surgeries) or disease complications.

In our study ultrasonography findings were considered to be further reviewed, by CT scan for four patients due to multiple organ involvement, suspected biliary tract involvement and complexity of disease The sensitivity of CT scan was about $100 \%$ in accurately diagnosing hydatid and acted as important tool for planning operative procedure.

Our study is comparable to both Pedrosa et al and Kalinova et al. ${ }^{8,11}$

The X-ray was the initial diagnostic modality of choice which usually shows, homogenous round or oval well shaped masses with smooth borders, surrounded by normal lung tissue. But in cases of infection or rupture, diagnosis may become atypical and in such situations CT becomes diagnostic modality of choice.

The two cases in our study, considered negative because X-ray don't shows any well-defined oval or circular margins and one patient had associated pleural effusion. Diagnosis was confirmed and operative intervention made only after CT scan with sensitivity of about $100 \%$.

Our study findings are equivocal with study of Sharifi et al145, with comparable sensitivity of Xray and $\mathrm{CT}$ scan for diagnosis of thoracic hydatid.

Use of serological tests for diagnosis was not reliable.

Partial cystectomy with omentoplasty was done in patients with simple hydatid cyst without any cystobiliary communications after through irrigation with scolicidal solution. External drainage was done for multi-loculated cysts and those with cystobiliary communications. The most common procedure applied was both omentoplasty and external drainage of cysts residual cavity, done for infected, ruptured, or cyst with prominent cystobiliary communications. The scolicidal agent used for irrigation of residual cavity was $2 \%$ cetrimide (savlon) in all patients. Results of omentoplasty and external drainage are good as compared to previous studies of Tariq E. Al-aubaidi and Sarmast et al. ${ }^{4,13}$

The incidence of complications in omentoplasty was about $11.12 \%$; in external drainage was about $16.67 \%$; and in combined omentoplasty and external drainage was about $53.84 \%$. Though the complications were higher in combined procedures, but they are most suitable for complicated hydatid cysts, while omentoplasty is best for simple hydatid cyst of liver.
Presence of cystobiliary communications was most common intraoperative complication (22\%), followed by contamination of abdominal cavity with scolices (16\%). Anaphylaxis was least common (2\%). These findings were comparable to the previous studies conducted by Langer et al and Silva et al. ${ }^{10,17}$

Out of 11 patients with cystobiliary communications, 10 had bile leak in postoperative period.

\section{Bile leak:}

Less than 7 days - 2 patients

Between 8- 14 days - 2 patients

More than 14 days - 5 patients

No bile leak - 1 patient

Contamination of abdominal cavity was observed in $16 \%$ of patients and it was mainly in intraoperative period because of rupture and spillage of hydatid cyst during puncture and sometimes due to spontaneous rupture of hydatid at the time of presentation. It was mainly responsible for recurrence of hydatid cyst.

The most common complication in post-operative period was biliary leak (20\%) followed by respiratory complications (14\%). These findings were comparable to the previous studies conducted by Langer et al and Silva et al. ${ }^{10,17}$

Most common type of wound infection in postoperative period was stich abscess $(8 \%)$, followed by localized erythema and induration (6\%), partial dehiscence (4\%), subcutaneous abscess (2\%), and total dehiscence (2\%). Post-operative bile leak occurred in patients with prominent cystobiliary communications and who were operated with partial cystectomy and external drainage

Recurrence of hydatid cyst was observed in about $6 \%$ of patients of liver hydatid. It was seen in those patients, in which there is either, rupture and spillage of scolices in the abdominal cavity.

Incisional hernia occurred in $4 \%$ of patients. In these patients, there was postoperative wound infection which resulwound healing and weak abdominal wall. It was managed by mesh hernioplasty in one patient, and conservatively in another with abdominal binder.

Death occurred in study group during intraoperative or postoperative follow up period. These findings 
were similar to those of previous studies of Silva et al and Langer et al. ${ }^{10,17}$

The mean duration of stay after surgery was about 9.34 days. Long duration of postoperative stay was seen in patients with complicated hydatid cysts, patients with prolonged bile leak and after thoracotomy. Newer treatment modalities like PAIR and laparoscopy may also reduce the duration of stay.

\section{CONCLUSION}

Hydatid disease is still a major problem in rural agricultural population. Surgery is most widely acclaimed procedure for treatment of hydatid and vary from site, size and organ involved. Good living condition and sanitation with mass education is the most effective for prevention of hydatid disease.

Funding: No funding sources

Conflict of interest: None declared

Ethical approval: The study was approved by the institutional ethics committee

\section{REFERENCES}

1. Christos A, Pissiotis, John V, Wander, Robert E Cenden. Surgical treatment of hydatid disease. Prevention of complications and recurrence. Arch Surgery. 1972;104:454-59.

2. Amir Jahed AK, Fardin R, Farzad A, Bakshandeh K. Clinical Echinococcosis. Annals of Surgery. 1975;182(5):541-46.

3. Torres RR and Campbell JR. An interpretative review of the surgical treatment of hydatid disease. Surgery Gynaecology and Obstetrics. 1965;121:851-61.

4. Hakan I, Tahir M, Zihni K, Selda S, Faruk C. Unusual locations of hydatid diseases: an evaluation of 77 cases. Turk J Gastroenterol. 2001;12(4):299-302.

5. Polat P, Kantarci M, Alper F, Suma S, Koruyucu MB, Okur A. Hydatid disease from head to toe. Radiographics. 2003;23:475-94.

6. Magistrelli P, Masetti R, Coppola R, Messia A, Nuzzo G, Picciocchi A. Surgical treatment of hydatid disease of the liver. Arch Surg. 1991;126:518-23.
7. Akther J, Khanam N, Rao S. Clinico epidemiological profile of hydatid diseases in Central India, A retrospective and prospective study. Int. J Biol. Med. Res. 2011;2(3):603-6.

8. Kalinova K. Imaging (Ultrasonography, computed tomography) of patients of hydatid liver disease. Bulg J Vet Med. 2007;10(1):4551.

9. Chowbey PK, Shah S, Khullar R, Sharma A, Soni V, Baijal M, et al. Minimal access surgery for hydatid cyst disease: laparoscopic, thoracoscopic, and retroperitoneoscopic approach. J Laparoendosc Adv Surg Tech A. 2003;13(3):159-65.

10. Langer JC, Rose DB, Keystone JS, Taylor BR, Langer B. Diagnosis and management of hydatid disease of liver: A 15 year-north American experience. Ann. Surg. 1984;199(4):412-7.

11. Pedrosa I, Saiz A, Arrozola J, Ferreiros J, Cesar S. Hydatid disease: Radiological and pathological features and complications. Radiographics. 2000;20(3):795-817.

12. Sharifi-Mood A, Fazaeli A, Sh Izadi, Mokhtari S. Fifteen years' experience with pulmonary hydatidosis in Zahedan, Iran. Iranian J Parasitol. 2007;2(7):7-11.

13. Tariq E. Al-aubaidi. Surgical treatment of hydatid cyst of liver. The Iraqi PG Med J. 2010;9(2):189-95

14. Sarmast MH, Firooziannezhad R, Maraghi S, Asl JM. Comparision of different surgical techniques in the hepatic hydatid cyst management. MJIS. 2003;6(1):37-9.

15. Schmidt-Matthiesen A, Schott O, Encke A. Surgery and long term follow up of hepatic ecchinococcosis outside endemic region. $\mathrm{Z}$ Gastroenterol. 2002;40(2):51-7.

16. Alfieri S, Doglietto GB, Pacelli F, Cortamanga G, Gurriero C, Multigmari M, et al. Radical surgery for liver hydatid disease: a study of 89 consecutive patients. Hepatogastroenterology. 1997;44(14):496-500.

17. Silva MA, Mirza DF, Bramhall SR, Mayer $\mathrm{AD}$, McMaster P. Treatment of hydatid disease of liver. Dig Surg. 2004;21: 227-34.

Cite this article as: Pothare AN, Deshpande AV, Nandu VV. Clinical study of hydatid disease. Int Surg J 2016;3:1564-9. 